\title{
JOURNAL.RU
}

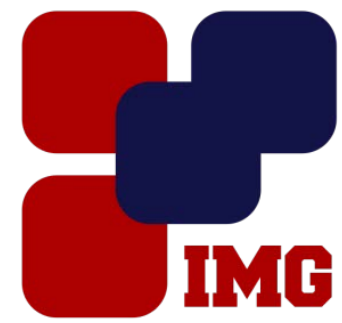
IYANOY Management GROUP

Акбашева Д. М., Капова С.С. Северо-Кавказская Государственная Гуманитарно-Технологическая Академия Черкесск, Россия

doi: 10.18411/lj-25-12-2016-3-02

idsp 000001:lj-25-12-2016-3-02

\section{Учет продуктивного и рабочего скота}

\section{Аннотация}

Важнейшей отраслью экономики России является сельское хозяйство, что в свою очередь создает задачи по правильному учету тех или иных отраслей. В данной статье мы постараемся раскрыть основные понятия продуктивного рабочего скота и способы его бухгалтерского учета.

Ключевые слова: сельское хозяйство, животноводство, продуктивный скот, рабочий скот.

Разведение крупного рогатого скота - наиболее обширная отрасль животноводства. Весь выращиваемый домашний жвачный скот этой отрасли относится к семейству полорогих.

Сам же скот можно разделить на продуктивный и рабочий. К продуктивному скоту можно отнести всех тех животных, которых используют в сельском хозяйстве или в спорте. К ним можно отнести лошадей, верблюдов, волов. Скот, который выращивается специально для получения от него какихлибо продуктов, называется продуктивным. [4]

Основное стадо продуктивного и рабочего скота формируется за счет перевода молодняка в основное стадо, приобретения взрослых животных и безвозмездного их получения. В бухгалтерском учете выделяют следующие расходы:

1) по выращиванию организацией собственного молодняка продуктивных и рабочих животных в целях последующего перевода в основное стадо;

2) по приобретению организацией взрослых животных у сторонних организаций и физических лиц в целях увеличения поголовья основного стада.

Принятие на учет собственного молодняка, выращенного в организации, отражается на субсчете 08-6 «Перевод молодняка животных в основное стадо». По дебету данного субсчета записывается сумма балансовой стоимости молодняка, переводимого в основное стадо, в корреспонденции с кредитом счета 
11 «Животные на выращивании и откорме». Переведенный молодняк одновременно списывается в дебет счета 01 «Основные средства» с кредита субсчета 08-6. Аналитический учет строится по данному субсчету таким образом, чтобы была возможность обособления информации о затратах по отдельным видам животных (крупный лошади, рогатый скот, свиньи и т.п.).[2]

Стоимость молодняка, переводимого в основное стадо, формируется из цены молодняка на начало года и затрат на выращивание в текущем году.

После того, как в конце года рассчитывается фактическая себестоимость затрат на выращивание молодняка животных, переведенных в течение года в основное стадо, на величину выявленной на счете 11 «Животные на выращивании и откорме» разницы делается дополнительная либо сторнировочная запись в дебет субсчета 08-6 «Перевод молодняка животных в основное стадо». Одновременно корректируется стоимость оприходованных животных, отраженная на счете 01-4 «Скот рабочий и продуктивный».

Для учета операций по приобретению взрослых животных для увеличения основного стада предназначен субсчет 08-7 «Приобретение взрослых животных».[1] По дебету данного счета отражаются все затраты, осуществляемые организацией в связи с покупкой животных, в корреспонденции с соответствующими счетами учета затрат:

Дебет счета 08-7 «Приобретение взрослых животных», Кредит счетов 60 «Расчеты с поставщиками и подрядчиками», 76 «Расчеты с разными дебиторами и кредиторами» и др.

Дебет счета 19 «Налог на добавленную стоимость по приобретенным ценностям», Кредит счетов 60 «Расчеты с поставщиками и подрядчиками», 76 «Расчеты с разными дебиторами и кредиторами»

Дебет счета 08-7 «Приобретение взрослых животных», Кредит счетов 23 «Вспомогательные производства», 70 «Расчеты с персоналом по оплате труда», 69 «Расчеты по социальному страхованию и обеспечению», 10 «Материалы», 76 «Расчеты с разными дебиторами и кредиторами».

Дебет счета 01-4 «Скот рабочий и продуктивный», Кредит счета 08-7 «Приобретение взрослых животных».

Взрослые животные, полученные безвозмездно, принимаются к бухгалтерскому учету по рыночной цене, к которой добавляют фактические расходы по доставке животных в организацию. Рыночная цена животных, полученных безвозмездно, учитывается на дебете счета 08 с кредита счета 98 «Доходы будущих периодов».[3]

Затраты по конченным операциям формирования основного стада списывают с кредита счета 08 «Вложения во внеоборотные активы» в дебет счета 01 «Основные средства». 


\section{Литература}

1. Бданциева, Л.Ж. Бухгалтерский учёт [Текст]: учеб. пособие/ Л.Ж. Бданциева.- М.: ИНФРА- М, 2011.- 735 с.

2. Широбоков, В.Г. Бухгалтерский учет в организациях АПК. [Электронный peсурс]: учебник/ Широбоков В.Т.- Электрон, текстовые данные.- М.: Финансы и статистика, 2013.- Режим доступа: http://iprbookshop.ru/12425.ЭБС «EPRbooks», по паролю.

3. Лисович, Т.М. Бухгалтерский учёт в сельскохозяйственных организациях [Текст]: учебник/ Т.М. Лисович.- М.: Финансы и статистика, 2011.- 456 с.

4. Пизенгольц, М.3. Бухгалтерский учёт в сельском хозяйстве. Т. 1.4.1. Бухгалтерский, финансовый учёт [Текст]: учебник/ М.3. Пизенгольц- 4-е изд., перераб. и доп.- М.: Финансы и статистика , 2012.- 488 с. 